it (which will be harder). Mr Baker's concept of a funding council is that of a 15 -member corporate body, presumably an appropriate mix of Britain's great and good (voluntary public servants), whose functions will differ from the existing University Grants Committee in having no continuing responsibility to advise the government on policy on higher education (which means less influence), will have the power to hire its own staff (which is a plus), will have to disburse money to universities and polytechnics "subject to such conditions" as Mr Baker and his successors may determine (why should not the bill say what the rules are?) but may be as beastly as it likes to its dependants ("subject to such terms and conditions as they may think fit"). Whether the government will be able to persuade trustworthy people to serve on such a public corporation is open to question. It has needlessly complicated its task of finding compliant servants by distinguishing between the "six and not more than nine" members "appearing ... to have experience of, and to have shown capacity in, higher education" and the remainder, who will be people with "experience of, and capacity in, industrial, commercial or financial matters". British academics may be forgiven for thinking that the present government has been seeking to abolish these distinctions.

The bill will also seem, to many academics, to be mean on academic tenure, but that is not the case. Mr Baker has elected to follow the suggestion of his precedessor, Sir Keith Joseph, that there should be a body of University Commissioners empowered to amend university statutes so as to abolish the right to academic tenure. The proposal is a direct infringement of the autonomy of universities, although not an infringement of the academic freedom of individual academics, for the bill straightforwardly declares that fair grounds for dismissal include the fact that a university has given up the activity for which the person was employed, or that it has decided to cut back on it. There is nothing in the bill to suggest that academics may be fired because, while still able teachers and researchers, they hold unfashionable or even subversive opinions. The universities now say they hope to see these provisions amended; they would be better advised to see that new contracts of employment conform with the provisions of the draft bill - and to keep their powder dry for more important issues.

The chief of these is that the bill lacks educational content. Nowhere is there a phrase, let alone a sentence, to suggest that the present British government is aware of how a once-considerable educational system has fallen, by neglect and as a consequence of harassment, into structural disrepair and moral despair. The government does not attempt, even in the most general language, to define the objectives of higher education. (Schools are meant to promote "spiritual, moral, cultural, mental and physical development" and to prepare young people for "the opportunities, responsibilities and experiences of adult life".) As well as ducking the question of access to higher education, the bill says nothing about the functions of the different kinds of institutions the government will be running by ministerial directive in the years ahead. The government's failure to promise to take advice on some of these difficult questions is presumably predicated on the assumption that it will retain political power for the rest of time, which may be unwise. The neglect of this opportunity to unify the two halves of British higher education (universities and, broadly speaking, the polytechnics) belies the aptness of the word "reform". The casual balkanization of British higher education (Scotland and Wales will be differently dealt with separately from England) is a mistake. And the bill is badly drafted; although the University Commissioners will be able to amend the statutes of all institutions that have taken the government shilling in the past three years, the institutions subject to the Universities Funding Council are undefined. Many people had been hoping for better from Mr Baker. Before this long parliamentary session is over, many of his then-sleepless political colleagues in the House of Commons will share that view.

\section{Figures for research}

Britain's research community must think harder about its funds, and how it spends them.

WHEN the British research councils had $£ 500$ million a year to spend, Mrs Margaret Thatcher, the prime minister, was fond of saying that " $£ 500$ million is a lot of money". Now, no doubt, she says that $£ 600$ million is a lot of money. She is, of course, right. So why does the British research community perpetually consider itself to be impoverished? In this season of annual reports from the research councils (see Nature 330,196; 1987 for three of them), the government's Annual Review of Government Funded $R \& D$ for 1987 , out this week, gives a simple explanation: the research community feels impoverished because it is being impoverished - government research spending is declining.

The decline is only marginal, but the direction of the trend accounts for the sense of hurt that has abounded in Britain throughout this decade. In terms of constant prices (those of 1985-86), spending by non-military government departments fell from $£ 1,007$ million in $1984-85$ to an estimated $£ 910$ million in this financial year, more than the increase of the research councils' spending during the same period of $£ 41$ million. Even military spending on research and development declined over the same interval, by coincidence no doubt by the same amount as research council spending grew, to $£ 2,226$ million.

On the same showing, there will be no end to the misery. Having grown a little, research council budgets are expected to decline in the two years immediately ahead, to $£ 551$ million (at 1985-86 prices) in 1989-90. During the same period, the Department of Trade and Industry will spend an extra $£ 33$ million, but this will be more than offset by a further decline of defence research spending of $£ 150$ million, when the total cost of military research will be less than half of all the British government spends on research and development for the first time in half a century. Even though some of these shifts of spending may be desirable in their own right, their effects can only be to sharpen the sense that people have that they work in a declining field of interest. So, in Britain, they do.

The joker in this pack is the credit the British government takes (with some measure of justice) for the research component of what it pays each year to keep the universities going - $£ 690$ million (at 1985-86 prices) in the current year. If $£ 600$ million is a lot of money, $£ 600$ million plus $£ 690$ million is twice as much that is what people may be saying. The trouble, of course, is that the government's contribution to research spending through the budgets of the universities is notional only; the sums concerned never materialize as disposable cash at the disposal of grantmaking committees, but consist chiefly of a proportion of the salaries of all academics, all of whom are notionally supposed to be engaged in research.

So why not turn some of that budgetary money into real cash? During the past few months, British researchers have been looking enviously at what the universities are notionally spending on research. They are right to do so, but they will succeed in their ambition only when they have put their own houses in order. The largest of the British research councils, the Science and Engineering Research Council, with a total budget of $£ 337$ million, was able to spend only $£ 100$ million on research grants to independent researchers; the rest of its income went on external research collaborations and in-house services devised in happier times to be of service to independent researchers. If, by the time the Medical Research Council has reported, total disposable income for $1986-87$ exceeds $£ 140$ million, most people will be surprised. The moral, for the research councils and the academic researchers who serve them, is that they must find a way of trimming these huge fixed costs. Then they might have a chance of persuading the government that a transfer of funds from the universities to the research enterprise - or from all universities to some - would be both equitable and wise. $\square$ 